Article

\title{
A Jewish America and a Protestant Civil Religion: Will Herberg, Robert Bellah, and Mid-Twentieth Century American Religion
}

\author{
Ronit Y. Stahl \\ John C. Danforth Center on Religion and Politics, Washington University in St. Louis, \\ One Brookings Drive, Campus Box 1066, St. Louis, MO 63130, USA; E-Mail: rystahl@wustl.edu; \\ Tel.: +1-314-935-8328
}

Academic Editor: Peter I. Kaufman

Received: 16 February 2015 / Accepted: 31 March 2015 / Published: 13 April 2015

\begin{abstract}
This essay reads Will Herberg's Protestant-Catholic-Jew alongside Robert Bellah's "Civil Religion in America" to illuminate how mid-century thinkers constructed, rather than merely observed, a vision of, and for, American religion. Placing Herberg in direct conversation with Bellah illuminates why Herberg's religious triptych depiction of America endured while his argument for an "American Way of Life"- the prototype for Bellah's widely accepted idea of civil religion—flailed. Although Herberg's "American Way of Life" and Bellah's "Civil Religion" resemble one another as systems built on but distinct from faith traditions, they emerged from intellectual struggles with two distinct issues. Herberg's work stemmed from the challenges wrought by ethnic and religious diversity in America, while Bellah wrote out of frustration with Cold War conformity. Both men used civil religion to critique American complacency, but Herberg agonized over trite formulations of faith while Bellah derided uncritical affirmations of patriotism. Bellah's civil religion co-existed with and, more importantly, contained Herberg's "Protestant-Catholic-Jew" triad and obscured the American Way of Life. In an increasingly diverse and divisive America, Bellah's civil religion provided a more optimistic template for national self-critique, even as Herberg's American Way of Life more accurately described the limits of national self-understanding.
\end{abstract}

Keywords: religion and politics; Protestant-Catholic-Jew; civil religion; Will Herberg; Robert Bellah 


\section{Introduction}

When first published in 1955, Will Herberg's Protestant-Catholic-Jew earned theologian Reinhold Neibuhr's applause as "the most fascinating essay on the religious sociology of America that has appeared in decades" [1]. Since then, Herberg's tripartite construction of religion in mid-twentieth-century-America has become a staple of scholarly and popular literature on religion and pluralism in the United States. ${ }^{1}$ For example, while pointing out that religion's resilience in the United States owed much to immigration, contemporary political analyst E. J. Dionne remarked, "Will Herberg wrote an important piece of religious sociology in 1955 called 'Protestant-Catholic-Jew'. If he were here now, his book would have to be named 'Protestant-Catholic-Jew-Muslim-Hindu-SikhBuddhist-Jain-Confucian.' And even that ungainly title wouldn't exhaust the possibilities" [10]. While Herberg wrote his landmark book during the nadir of twentieth-century immigration [11], much has changed since then. ${ }^{2}$ In 1965, Congress loosened immigration restrictions, and as Dionne recognized, a multitude of believers from across the globe flowed into the United States. To make sense of this new ethnic and religious mosaic, Dionne plucked a mid-twentieth-century frame that seemed malleable, yet is actually quite anachronistic. Nevertheless, Dionne's invocation of Herberg's Protestant-Catholic-Jew underscores its persistence in commentary on American religious life.

References to Herberg's work, especially its "triple melting pot" thesis ${ }^{3}$ —in which religion remained the core distinction among Americans whose ethnicity had dissipated over time-are common yet frequently misconstrue the book's argument in two ways. First, they tend to substitute a desired interpretive flexibility for Herberg's analytical rigidity, and second, they neglect Herberg's concern with what he deemed "the American Way of Life", or "the operative faith of the American people". This "way of life" represented a creedal system that unified the American people around important tenets-democratic idealism, pragmatic individualism, idealistic moralism-and events celebrated by Americans. It existed alongside and in a reciprocal relationship with Protestantism, Catholicism, and Judaism ([11], p. 75). The American Way of Life represented what some called "civic religion" and what sociologist Robert Bellah would label "the American Civil Religion" in an essay published 12 years later. ${ }^{4}$ In his 1967 essay "Civil Religion in America", he wrote, "While some have argued that Christianity is the national faith, and others that church and synagogue celebrate only the generalized religion of 'the American Way of Life', few have realized that there actually exists alongside of and rather clearly differentiated from the churches an elaborate and well-institutionalized civil religion in America" ([15], p. 1). Bellah's essay instigated decades of scholarship on the historical, sociological, and theological dimensions of civil religion in the United States [16]. Yet as Philip Gleason observed in his retrospective examination of Protestant-Catholic-Jew, "the vast outpouring of scholarship on civil religion" generated by Bellah's article all but ignored Herberg

\footnotetext{
Kevin Schultz examines how Herberg's idea became a social reality in [2]. On pluralism more generally, see [3-9].

On shifts in American immigration policy in the mid-twentieth century, see [12,13].

Herberg adopted and then explored the ramifications of Ruby Jo Kennedy's term "triple melting pot".

4 Bellah presented his ideas about civil religion in a series of lectures in Japan in 1961 and his argument for civil religion at a May 1966 American Academy of Arts and Sciences conference on Religion in America. The presentations were published together in the Winter 1967 issue of Daedalus ([14], pp. vi, vii).
} 
"despite his extended attention to the subject" ([17], p. 61). ${ }^{5}$ Thus in the half-century following the publication of Protestant-Catholic-Jew, the potent phrasing of the work's title became the book's most well-known legacy while Herberg's contributions to an emerging body of scholarship on civil religion faded from sight.

Civil religion was not new in 1955 or in 1967. But as Raymond Haberski has recently argued, "the era since 1945 has witnessed a merging of American promise and power to forge a potent civil religion" ([18], p. 9). In mid-twentieth-century America, Will Herberg and Robert Bellah represented the foremost thinkers and sociologists of religion in American life. Placing Herberg more directly in conversation with Bellah illuminates why Herberg's depiction of the United States as a religious triptych endured while his argument for an "American Way of Life" flailed. Although Herberg's "American Way of Life" and Bellah's "Civil Religion" resemble one another as systems built on but distinct from faith traditions, they emerged from intellectual struggles with two distinct issues. Herberg's work stemmed from the challenges wrought by ethnic and religious diversity in America, while Bellah wrote out of frustration with Cold War conformity. Both men used civil religion to critique American complacency, but Herberg agonized over trite formulations of faith while Bellah derided uncritical affirmations of patriotism. Hence while each constructed a vision of civil religion derived from Durkheimian definitions of religion, Herberg emphasized morality while Bellah highlighted community. In addition, Herberg's argument for a "Protestant-Catholic-Jewish" America depended on his subtle framing of Jews as modal, rather than minority, Americans. In contrast, Bellah's civil religion melded Protestantism and nation, creating an American civil religion that could effectively Protestantize Catholics, Jews, and others. Thus Bellah's civil religion co-existed with and, more importantly, contained Herberg's "Protestant-Catholic-Jew" triad and obscured the American Way of Life. In an increasingly diverse and divisive America, Bellah's civil religion provided a more optimistic template for national self-critique, even as Herberg's American Way of Life more accurately described the limits of national self-understanding and American pluralism.

\section{An American Jewish Thinker: Will Herberg}

Herberg's contemporaries, whether theologians, sociologists, or interested observers, deemed Protestant-Catholic-Jew important precisely because it renewed attention to religion in America and prompted additional work dedicated to understanding its place and role. While commentators like Dionne want to see Protestant-Catholic-Jew as a foundational text asserting a liberal American pluralism that makes space for a multitude of religions, Herberg argued for something quite different, what historian Healan Gaston recently deemed "a more exclusive edge to Herberg's thought" ([19], p. 1133). As Edward Shapiro has written, a close reading of Protestant-Catholic-Jew reveals Herberg's more subtle claim: "instead of Jews conforming to Christian America, Christians were conforming to the pattern of ethnic and religious identity exhibited particularly by Jews" ([20], p. 271). In so doing,

5 Bellah did not mention Herberg as the origin of the phrase "the American Way of Life". Elsewhere in the essay, Bellah cited Protestant-Catholic-Jew as the source of an Eisenhower quote, which indicates his familiarity with the text and suggests that Bellah wrote, at least in part, in response to Herberg. Moreover, Bellah's use of Herberg's expression suggests that it was sufficiently well-known to deploy without a citation. 
Herberg presented an argument for a very particular, rather than capacious, and ideal, rather than real, view of American religion. ${ }^{6}$ Indeed, Protestant-Catholic-Jew reflected an intellectual agenda dedicated to a critique, rather than endorsement, of mid-century American religiosity.

The co-existence of religious behavior and secular worldviews animated Herberg's study. Challenged by the "paradox [of] pervasive secularism amid mounting religiosity", Herberg attempted to make sense of the contradictions he found among mid-twentieth-century Americans. To understand what he called the "religious situation", Herberg turned to historian Oscar Handlin's thesis that America could only be understood as a nation of immigrants. The array of local (European) peoples from distinct origin points consolidated into ethnic groups upon arrival on American soil; these ethnic groups, frequently delineated by language, unified according to their religion, or quite literally, within their ethnic churches. He defined ethnicity as the intersection of national origin, language, and religion. Without all three of these elements, it would be impossible to distinguish German Lutherans from German Catholics or Polish Catholics from Polish Jews. Similarly all three characteristics were necessary to group together Northern and Southern Italians or the mass of Eastern European Jews as single ethnic groups ([11], pp. 2, 27-41).

Herberg argued that religion provided the mechanism through which ethnic groups could both Americanize and retain in-group ties. Although he never explicitly defined religion, he hinted at an explication of religion. As a "divine-human encounter", religion is both transcendent and pragmatic. Yet "the final mystery" that is religion precludes analysis, and Herberg therefore attended to only the social and cultural manifestations of religion. Sociologically, he used statistics measuring church membership, church attendance, and Sunday school enrollment to discuss religion, viewing it as a link to family, as a means to self-identification, and as a foundation of communal social structure. Psychologically, he posited, religion emerges from "inner necessity", offers a sense of peace and security, and protects individual authenticity. Asserting that "religion, like the family, is one of the enduring, elemental institutions of mankind", Herberg framed religion as a historical entity. Theologically, he found a foundation for religion in faith and belief in God, statements commonly affirmed by Americans in national surveys.

Herberg's most explicit characterization of religion surfaced in his attempts to elaborate his idea of the American Way of Life. He wrote,

$[\mathrm{O}]$ ver and above conventional religion, there is to be found among Americans some sort of faith or belief or set of convictions, not generally designated as religion but definitely operative as such in their lives in the sense of providing them with some fundamental context of normativity and meaning. What this unacknowledged "religion" of the American people is, and how it manages to coexist with their formal religious affirmations and affiliations, is now our task to investigate ([11], p. 74).

"Conventional religion" and the "unacknowledged religion of the American people" share certain fundamental qualities, and the overlap described by Herberg disclosed the broad contours of his interpretation of religion. In his analysis, religion centered on "faith or belief or [a] set of convictions" and yielded "some fundamental context of normativity and meaning." This definition avoided theism

6 See also ([21], pp. 231-49). 
and supernaturalism, focusing instead on the utility of religious strictures and structures: guidance, meaning-making, and morality ([11], pp. 4, 39, 51-55, 60-61, 74).

Herberg implicitly borrowed from French sociologist Emile Durkheim's conception of religion. In The Elementary Forms of Religious Life, Durkheim determined that "a religion is a unified system of beliefs and practices relative to sacred things, that is to say, things set apart and forbidden - beliefs and practices which unite into one single moral community called a Church, all those who adhere to them" ([22], p. 44). In contrast to Durkheim, who used "the simplest and most primitive religion" to adduce the principles of and explain the basic elements of religion ([22], p. 1), Herberg surveyed the pluralistic American "religious situation" to discuss religion. In focusing on the social rather than theological dimensions of religion, Herberg shared with Durkheim the intuition that religion reflects unified moral communities. Both dismissed definitions of religion that derive principally from belief in God or another supernatural being. However, the implicit view of religion proffered by Herberg also diverged from Durkheim because Herberg ignored the sacred/profane dichotomy at the heart of Durkheimian analysis. Worship and rituals accorded importance in supporting the sacred/profane division in Durkheim did not appear in Herberg's observations about religion in American life, and the first part of Durkheim's argument, that religion is "a unified system of beliefs and practices relative to sacred things", was absent from Herberg's work ([11], p. 4).

Thus when Herberg stated that immigrants "inevitably transformed the church they thought they were transplanting" ([11], p. 11), he referred to the church metonymically, as a unit representing the social organization of religion. Indeed, reviewing Protestant-Catholic-Jew from across the Atlantic, D. W. Brogan identified "the acceptance by 'America' of these three organizations (one can hardly say forms of belief) as really American” as a major component of the book ([23], p. 4). Brogan's wry parenthetical underscored Herberg's sociological orientation. Why does this matter? Drawing on earlier work on immigration, Herberg altered the configuration of the "melting pot". Whereas earlier scholars viewed the American cauldron as a true mixture of European cultures, Herberg recognized the hegemony of the Anglo-Saxon, or white, Protestant, Western European, ideal. The "transmuting pot", as he labeled it ([11], p. 21), described the space and goals of American cultural assimilation. For all that immigrants had to adapt to prevailing cultural norms, they could keep their religion, and it was this religious retention that fascinated Herberg.

By turning Marcus Hansen's aphorism, "What the son wishes to forget, the grandson wishes to remember" into "Hansen's Law", Herberg mobilized generational change in support of his analysis of religion and secularism as a non-combative pair. Forced to shed previous nationalities and languages in favor of American identity and English, immigrants worked hard to integrate into American life. Thus, consonant with Hansen's work, Herberg found that the second generation attempted to shed foreign attributes and reject ethnic-religious ties, while the third generation sought to re-establish connections to the past and reinvigorate religious observance. Amidst this assimilatory shuffling of communal allegiances, immigrants experimented with a variety of social identifiers. Religion remained the constant — an acceptable mode of affiliation with disappearing ethnic groups.

The enduring presence of religion in American society propelled Herberg to assert: "to be an American today means to be either a Protestant, a Catholic, or a Jew" ([11], p. 40). The argument that American identity demanded membership in one of these three faith traditions encompassed two inter-related claims: first, that Protestants, Catholics, and Jews stood equal to one another and second, 
that these faiths coexisted with the American Way of Life. What do these contentions mean within Protestant-Catholic-Jew and how did early reviewers respond to them?

Herberg wrote, “the three 'communions'—Protestantism, Catholicism, Judaism - [are] three diverse, but equally legitimate, equally American, expressions of an over-all American religion, standing for essentially the same 'moral ideals' and 'spiritual values"' ([11], p. 87). Placing Catholicism and Judaism alongside Protestantism as equal participants in American society and culture significantly elevated their status. While Herberg acknowledged that Protestants remained the largest religious conglomerate in America, with 68 percent of the population self-identifying as such, he downplayed the magnitude of making Catholicism and Judaism mainstream. ${ }^{7}$ Together, Catholics and Jews comprised about one-quarter of the mid-twentieth century American population, but Herberg resisted any suggestion that they constituted religious minorities. Instead, he positioned them as central components - or even compasses - of American life. An early review in The American Catholic Sociological Review explicitly questioned the legitimation of Protestantism, Catholicism, and Judaism as equals in the United States. John Kane, a Catholic sociologist praised by S. Joseph Fauman in Jewish Social Studies as a more sensitive interlocutor with pluralism than Herberg, pointed out that the triumph of religion over ethnicity remained uncertain, and discrimination against Catholics and Jews persisted. Less concerned with the problem prejudice posed for Herberg's work, J. Milton Yinger, a secular Jew appraising Protestant-Catholic-Jew in the American Sociological Review, wondered whether obstacles to Americanization altered Catholicism and Judaism superficially or deeply. He suggested that, on the one hand, symbolic similarity among the religions may obscure larger differences and, on the other hand, Herberg ignored the ways in which religious communities shed their distinctiveness to engage with one another in "the many associations that cut across religious lines." These concerns notwithstanding, Yinger found Herberg invigorating [24-26].

7 Statistics of American religious identification offered some useful information but also created certain challenges. On the one hand, Herberg cited 1953 survey results showing self-identification: $68 \%$ as Protestant, $23 \%$ as Catholic, 4\% as Jewish, and 5\% as no preference. A 1955 Gallup poll yielded similar results: $70.8 \%$ of Americans said they were Protestant, 22.9\% Catholic, 3.1\% Jewish, and 3.1\% other or none. On the other hand, studies of church membership reveal a larger group of "unchurched" Americans. Data from the 1960 Yearbook of American Churches offers the following numbers: $35.5 \%$ of Americans belong to Protestant churches and $22.8 \%$ belong to Catholic Churches. Synagogue membership does not appear in that table. These data suggest that Catholic self-identification coincided with church membership, but Protestant self-identification tracked poorly with church membership. It is also important to note that Herberg did not clarify where certain groups, such as Mormons, counted as Protestant or other ([11], pp. 46, $65,160)$. In the late 1950s, the Bureau of the Census considered adding a religion question, and a March 1957 trial survey of religious affiliation suggests that Jews comprised a little over three percent of the United States' population. However, as Kevin Schultz documents, many-though not all-Jewish groups mobilized against including a religion question on the United States Census for emotional and/or legal reasons: they feared that cross-tabulations of religion and wealth would create fodder for antisemitic hate-mongering while revealing the locale of Jews and they believed that constitutional guarantees of free exercise of religion demanded religion remain private and invisible to the state. See ([2], pp. 159-78). 


\section{The American Way of Life: Herberg's View of Civic Religion}

For Yinger, Herberg's conception of the American Way of Life was significant precisely because it raised critical questions about functional needs for commonality within America and across nations more generally [26]. Indeed, Herberg's trio of faiths worked together to support the American Way of Life. They neither competed with one another nor with rival "civic religion." Commitment to Protestantism, Catholicism, or Judaism symbolized and cemented a commitment to the American Way of Life which, Herberg repeatedly emphasized, was not itself a religion. Inasmuch as he used the term "civic religion", Herberg resisted characterizing the American Way of Life as a religion. To do so-as some of his contemporaries did - would push the ideology too far. "The American Way of Life", he concluded, "is not avowed as a super-faith above and embracing the historic religions. It operates as a 'common faith' at deeper levels, through its pervasive influence on the patterns of American thought and feeling. It makes no pretensions to override or supplant the recognized religions, to which it assigns a place of great eminence and honor." To be clear, while Herberg recognized that the American Way of Life resembled religion, he refused to categorize it as such. Concerned with the rise of a therapeutic "cult of faith" that diminished the theocentric trio of religions he admired, he resisted the American Way of Life as too facile and underwhelming to achieve the status of religion ([11], pp. 75, 88-89). Thus he castigated the American Way of Life for "devitaliz[ing]...the historic faiths" by fostering "an inner, personal religion that promises salvation to the disoriented, tormented souls of a society in crisis" ([11], pp. 88-89). Finally, because "civic religion is a religion which validates culture and society, without in any sense bringing them under judgment," it could do little to critique "national self-righteousness" ([11], p. 263).

The degree to which the American Way of Life coalesced into a religion concerned several of Herberg's early reviewers. Writing in The Review of Politics, Catholic Thomas McAvoy worried that the American Way of Life approximated a religion, but otherwise agreed that "promoting the democratic tolerance of differences" was important and good so long as it did not "foster any religious nationalism" [27]. Some, however, appreciated the Herberg's distinction. Alban Baer's review in Commonweal, a Catholic publication, celebrated Herberg's accomplishment "even if some of its implications are uncomfortable." In particular, he declared, "The last chapter, 'Religion in America in the Perspective of Faith', is the crown of the whole work, for it is here that Mr. Herberg is concerned to show exactly what is the nature of American religion and how by implication it falls short of true religion" [28].

Still others felt Herberg's own religious inclinations prevented him from recognizing the full ramifications of the American Way of Life. According to H. L. Short, for example, "His own theology is of the modern neo-orthodox type, which (I would respectfully suggest) is inclined to be censorious. He nowhere considers the possibility that, in spite of all the defects he sees, something new may be emerging in America. Pragmatic idealism may be the genuine twentieth-century mould of the ancient Jewish-Christian tradition" [29]. Jack Cohen cast the problem of an "American religion" as elucidated by Herberg in different terms. Unlike Short, who agreed with Herberg that American who unify over a certain moral instinct, Cohen disputed both the presence and desirability of such agreement - while also attributing the defect to Herberg's own religious beliefs. Offering a review to the Jewish readership of The Reconstructionist, Cohen stated, "Herberg, it seems to me, permits his prejudice for his existentialist 
faith to lead him astray". He proceeded to explain that Herberg misjudged the American Way of Life by assuming coherence rather than critique, by devaluing "democratic interchange" and "open criticism of prevailing institutions". Moreover, he asked, "are there not points of conflict between the spiritual outlook of Americans as Americans and what they are taught as Christians or Jews...If there are conflicts, is not Herberg's reduction of American religion to an inferior or 'secularist' version of religion prejudging an issue which deserves considerable open study?" [30].

Against the concerns brought forth by Short and Cohen, John Bennett, a Union Theological Seminary professor of Christian theology and ethics, insisted that Herberg "is unique and the only person who could have written this book or anything like it" [31]. Herberg's background as a Jew who studied with Niebuhr and wrote for Catholic publications allowed him insight others lacked. Indeed, in its entirety, Bennett's assessment resembled that of many Protestant reviewers: it summarized the book without judging Herberg's treatment and evaluation of Protestants. While Catholics and Jews freely opined about Herberg's handling of their and others' religious experiences, Protestants were more cautious and less forthright, perhaps out of fear that they would appear intolerant if they attempted to correct Herberg. When they signaled concern, more often than not, it related to secularism. In The Journal of Religion, Gibson Winter offered a typical reservation, that Herberg's generalizations about secular trends may not have reflected reality. Despite this, Winter admired the book and agreed (without irony) that "the American way [is] the common faith" [32].

Regardless of the reviewer's stance on Protestant-Catholic-Jew, almost all of the critiques contained a common refrain: the book was vital to anyone interested in American religion. Like Niebuhr, John Bennett called Protestant-Catholic-Jew "one of the most illuminating books I have read about the actual religious situation in America" [31]. Even the most recalcitrant critics celebrated the value of Herberg's work. For example, Lee Braude, who refused to accept Protestant-Catholic-Jew as a sociological work, maintained "the insights and speculations which Herberg does present might prove useful for future research of a more vigorous character. And it is in this area that the sociologist should find the book of value" [33]. While Braude impugned Herberg's sociological credentials, Samuel Sandmel, a Hebrew Union College professor, derided Herberg's theological analysis. As he noted in his introductory paragraph, "I have a greater regard for the earnestness of Herberg's theological intent than for his achievements. I cannot take him seriously as a theologian." Despite this qualm, Sandmel, like Braude, admired Herberg's "useful and perceptive" contributions and foresaw the importance of Protestant-Catholic-Jew as a historical document. He bluntly proclaimed, "it is not of great moment whether Herberg's thesis is right or, as I believe, only partly right; it does not matter even if his thesis is totally wrong...he says very many illuminating things about religion in the United States with clarity and with insight, and with a fine sense of balance" [34]. ${ }^{8}$

8 Sandmel was one the few reviewers to comment upon the validity of the third-generation thesis when applied to Protestants. He agreed that it applied to Jews and Catholics, based on his own experience within the Jewish community and his observations of Catholics in New Haven. Turning to Protestants, however, Sandmel rejected Herberg's argument, finding the experiences of the small numbers of recent Protestant immigrants and native-born American Protestants too different to fit the third generation revival of religion described by Herberg. He drew upon the knowledge he acquired as a faculty member in Vanderbilt's nondenominational Protestant divinity school to make this claim. While several reviewers taught at either Union Theological Seminary or the University of Chicago Divinity School, none of those reviews rebuffed Herberg's thesis in regard to Protestants. 
The volume of reviews attests to the importance of Protestant-Catholic-Jew in the 1950s. As a widely-discussed thought-piece, it provoked a lot of discussion, and as commentary on the state of religion in America, it generated a lot of acclaim. Prior to the publication of Protestant-Catholic-Jew, Herberg, the former Marxist turned neo-orthodox critic, drifted from one academic post to another. A City College dropout who thrived as an intellectual and teacher at the Marxist-Leninist/New Workers School, Herberg eschewed formal educational credentials in favor of independent scholarship and lecturing. The International Ladies Garment Workers Union and a college lecture circuit provided audiences, but Herberg had to scurry to find semi-regular employment and compensation. After the publication of Protestant-Catholic-Jew, the wandering Jew found himself a home at Drew University, a Methodist college in New Jersey. Despite a permanent job-Herberg taught at Drew from 1955 until his death in 1977-the professor without a Ph.D. never fit perfectly in the towers of academe ([35], pp. 2-3, 69, 108, 136-52, 211). But job security did little to bring Herberg's intellectual agenda to the fore. Esteemed in the fifties for its descriptions, if not for its argument, Protestant-Catholic-Jew lost its luster in the next decade. While Herberg worried about an "official piety" that produced "a kind of national messianism which sees as the vocation of America to bring the American Way of Life, compounded almost equally of democracy and free enterprise, to every corner of the globe...[or] in more mitigated versions, it sees God as the champion of America, endorsing American purposes, and sustaining American might", the Cold War marched on. The 1950s and 60s continued to pit the United States against the Soviet Union, religion against atheism, and democracy against communism. ${ }^{9}$ However, from Herberg's perspective, the problem ran much deeper than geopolitical warfare, for something was rotten in the United States of America. Without "the God of judgment", Herberg asserted, American religion and the American Way of Life were vacuous. Religious diversity was important, but limited. Yet few discussed the sharp notes of discord on which Will Herberg concluded Protestant-Catholic-Jew, and fewer still took up his concerns with the American Way of Life justifying vapid "peace of mind" philosophy rather than deep engagement with faith ([11], pp. 264-65).

\section{An American Protestant Thinker: Robert Bellah}

Robert Bellah also worried about the use of civil religion for nefarious ends, but he saw potential where Herberg saw disaster. That Robert Bellah became the key figure in questions about civil religion in America was quite accidental. As a Fulbright scholar in Japan in the early $1960 \mathrm{~s},{ }^{10}$ his hosts asked him to explain the role of religion in American public life, and he answered with an analysis of references to God in President Kennedy's inaugural address. His lectures in Japan served as the origins

9 There is a growing historical literature on the role of religion in American Cold War politics (see [36-40]). But Herberg was less concerned with policy implications and more concerned with the preference for religion as "spiritual anodyne" that denuded religion, stripping it of judgment and meaning ([11], pp. 267-72).

10 While Herberg followed an unconventional, though prolific, path to the publication of Protestant-Catholic-Jew, Robert Bellah followed a more linear path through the channels of elite institutions to academic esteem. After receiving his B.A. from Harvard in 1950, he remained in Cambridge to complete his Ph.D. in sociology and Far Eastern languages in 1955. At Harvard, Bellah moved from his undergraduate work on Apache kinship (published by Harvard University Press) to his doctoral investigation of Japanese religion. Through a postdoc at McGill, he immersed himself in studies of Islam before returning to Harvard as an assistant professor of sociology ([14], pp. vi-vii, xv; [41]). 
for his landmark 1967 essay, "Civil Religion in America", which in turn spun his career away from foreign cultures and toward numerous examinations of his own American one ([14], p. viii). By the late 1960s, few academics recalled or even referenced Herberg's extended argument about the American Way of Life and civic religion. Nevertheless, "Civil Religion in America" built on many of the ideas presented in Protestant-Catholic-Jew. As a product of a sociologically-trained academic rather than a theologically-grounded public intellectual, as a product of the 1960s rather than the 1950s, and as a product of an intellectual agenda searching for a foundation for Civil Rights activism and anti-war protest rather than rising concern with insipid faith, Bellah's "Civil Religion in America" diverged from Herberg's "American Way of Life" in small but significant ways. It too cautioned Americans about the dangers of symbolism over substance, but it offered an optimistic read of American potential for self-critique and change.

Bellah's time abroad - in Japan and Canada_reflected more than academic postings: they were escapes from American anti-Communist loyalty oaths instituted by many institutions of higher education in the United States and a time, therefore, of political reckoning [41]. American efforts to root out subversives prompted Bellah's own "chastened liberalism." ${ }^{11} \mathrm{He}$ later recalled: "For all its failures, I came to believe that American society needed to be reformed rather than abandoned...Here was the Protestantism of my childhood transmuted through the deepest encounter with the twentieth century." When he moved from Montreal to Massachusetts in 1957, Bellah returned to Cold War America, albeit a slightly more subdued post-McCarthyite one. Turbulence was never far afoot, however, and while McCarthy's domestic interrogations ceased, threats moral and martial did not. Out of the depths of twentieth-century American life, especially the "horror at the profoundly immoral and unjustified war in Vietnam", came Bellah's sustained attention to religion in America; with his publication of "Civil Religion in America" in 1967 and move to Berkeley that same year, he cemented his interest in advancing sociology of religion through comparative work on multiple nations as well as inwardly-directed critiques of American society ([43], pp. xiv, xvii).

Both Bellah and Herberg wrote prior to the post-1968 influx of immigrants and rise of the religious right. ${ }^{12}$ However, whereas Herberg wrote about the American Way of Life at the height of the Cold War, Bellah worked on civil religion under the shadow of the looming war in Vietnam. Socially, Cold War conformity bolstered Herberg's thesis, with President Eisenhower's claim that faith - of any sort—supporting the idea that three religions could coalesce into the bedrock of civic religion. ${ }^{13}$ Likewise, Protestant-Catholic-Jew entered a market full of theological tracts, from Thomas Merton's autobiographical Seven Storey Mountain (1949) and Reinhold Niebuhr's theologically-informed The Irony of American History (1952) to Paul Tillich's Systematic Theology (1951) and Abraham Joshua Heschel's Man Is Not Alone: A Philosophy of Religion (1951). ${ }^{14}$ A decade later, in contrast, Bellah mulled over religion against the backdrop of Time Magazine's famous 8 April 1966 cover

11 In several essays, Bellah discussed his upbringing in the liberal Protestant tradition, his brief flirtation with Marxism, and his surprise at the interest in and fame accorded "Civil Religion in America" ([42], pp. 255-76).

12 Bellah further developed the idea of "Civil Religion in America" in [14] which derived from a series of lectures he gave at Hebrew Union College/Jewish Institute of Religion in 1971.

13 On Cold War American society and the construction of consensus politics, see [44-47].

14 On book culture and the implantation of liberal Protestantism into American cultural life, see [48]. 
proclaiming what Herberg had long feared-“God is Dead". Postwar anti-Catholicism had given way to a Catholic president, and to the extent that religion factored into public debate, its demise rather than its promise seemed to matter most.

How, then, did Bellah conceive of civil religion? Like Herberg, Bellah saw civil religion as concurrent with and distinct from the religion of church and synagogue. He also lamented the dearth of work on American civil religion; in a footnote, he mused that "why something so obvious has have escaped serious analytical attention is in itself an interesting problem." Without mentioning Herberg, Bellah proffered several reasons for the absence of work on civil religion, ranging from the controversy it generated to Western sensibilities that, in contrast to Asian beliefs, assumed allegiance to only one religion at a time and denied religion's presence outside church settings. Determined to resist this type of thinking, Bellah argued that religion was present in all groups or collectives, referring to both the example of the Asian societies with which he was most familiar and to the thought of sociologist Emile Durkheim. After acknowledging an intellectual debt to political theorist Jean Jacques Rousseau, Bellah traced the trail of civil religion from the early American republic through the inauguration of Lyndon Johnson in the twentieth century ([15], pp. 5, 19).

With particular attention to the language, themes, symbols, monuments, and rituals of presidents and the nation, Bellah charted the stages of a civil religion "shaped [in] tone and form" by George Washington, John Adams, and Thomas Jefferson and "selectively derived from Christianity...[but] clearly not itself Christianity". The Almighty Being appeared in the first inaugural address and the first Thanksgiving Day proclamation in $1789 .{ }^{15}$ Similarly, many creation narratives from the founding era allude to the biblical story of Exodus - from Egypt (Europe) to the Promised Land (America). Thus in its original incarnation, "a collection of beliefs, symbols, and rituals with respect to sacred things and institutionalized in a collectivity" comprised American civil religion. Here Bellah's language borrowed directly upon the first half of Durkheim's definition of religion as "a unified system of beliefs and practices relative to sacred things, that is to say, things set apart and forbidden-beliefs and practices which unite into one single moral community called a Church, all those who adhere to them." ${ }^{\text {"In }}$ contrast to Herberg who used the latter part of Durkheim's definition, the emphasis on "one single moral community", Bellah highlighted the components of Durkheim's religion (beliefs and practices) and the purpose of these component parts (they exist to demarcate "sacred things"). The "institutional collectivity" referenced Durkheim's "community called a Church" but de-emphasized its singularity and morality ([15], pp. 7-8; [22], p. 44).

The institutional collectivity had not, of course, been stable. The Civil War threatened and then reinvigorated civil religion. The nineteenth-century conflict challenged the nation to (re)define itself, and Abraham Lincoln served as president and chief meaning-maker for the divided population. As articulated by Lincoln, "death, sacrifice, and rebirth" become central components of American civil religion, institutionalized at Arlington National Cemetery and established through Memorial Day observances. Just as "the earlier symbolism of civil religion had been Hebraic without being in any specific sense Jewish", so too Bellah argued, "the Gettysburg symbolism [of redemption and rebirth]...is

15 In executive branch speeches, the term God first appeared in James Monroe's second inaugural address in 1821.

16 Durkheim's influence on Bellah's thinking can be traced to his graduate training when he saw in Durkheim, Max Weber, and Talcott Parsons a compelling alternative to Marxist views of history ([43], p. xiv). 
Christian without having anything to do with the Christian church." Civil War-era civil religion borrowed the symbols and language that resonated with Christian America to bring together a reborn nation. Created out of the selective appropriation of religious elements, civil religion never attempted to antagonize or supercede other faiths. It even created its own "annual ritual calendar" that includes Thanksgiving, Memorial Day, Veterans Day, the fourth of July, and Presidents Day to sustain the nation through "cultic celebration of civic rituals" ([15], pp. 10-11). ${ }^{17}$

Historicizing civil religion led Bellah to conclude that in its ideal form, civil religion "is a genuine apprehension of universal and transcendent religious reality as seen in or, one could almost say, as revealed through the experience of the American people." He acknowledged that individuals, groups, and leaders can mobilize civil religion for odious goals - as evidenced by its use to justify slavery, "the shameful treatment of the Indians," and contemporary attacks on liberals and nonconformists by groups such as the John Birch Society. Here Bellah revealed his political and intellectual agenda, arguing that civil religion was best used to advance civil rights and became dangerous when used to justify military intervention in Vietnam. Yet the possibility for "deformations and demonic distortions" notwithstanding, Bellah viewed civil religion as positive and as good as other forms of religion: "I am not at all convinced that the leaders of the churches have consistently represented a higher level of religious insight than the spokesmen of the civil religion." Where Herberg emphasized the deleterious effects of the American Way of Life on Judaism and Christianity, Bellah advocated American civil religion, seeing it as a powerful force for good. ${ }^{18}$ Historically, it helped birth independence and bridge the chasm of slavery; in the present, Bellah wrote, it could help America address "the problem of responsible action in a revolutionary world". Civil religion could thus remind Americans of a "higher judgment" and prevent citizens from blindly "worship[ping] the American nation". Unlike Herberg, who feared the American Way of Life sanctifying inward-driven individuality, Bellah stressed the outward-looking communal dimension of civil religion ([15], pp. 12, 14, 16-18). From his vantage point, civil religion was noble. It represented the best mechanism for urging American self-examination in order to turn away from wickedness and toward righteousness. ${ }^{19}$

\section{Conclusion: A Jewish America and a Protestant Civil Religion}

While Herberg and Bellah share the conviction that American civil religion, no matter the form, did not displace other religions, they strongly disagreed about the form and nature of civil religion. ${ }^{20}$ Herberg's American Way of Life was historical only insofar as waves of immigration and subsequent

17 Bellah published the essay prior to the assassination of Martin Luther King, and the process by which MLK Day commemorations became standard across the country supplies evidence for an evolving-and incrementally more inclusive-civil religion.

18 In offering a definition of civil religion, Bellah gestured toward a Weberian ideal type.

19 Bellah did not retain this optimism. He regarded his longer 1975 book on civil religion, The Broken Covenant, as "a jeremiad intended to change America" ([14], p. x).

20 Herberg and Bellah also share certain blindspots in their respective readings of America. Neither attends to the ways gender or class differences might affect participation in and understandings of American unity. While Bellah is more attuned to race, through the references to slavery and civil rights, he does not suggest that African-Americans might experience civil religion differently. Herberg ignores African-American Protestants in his assessment of American Protestantism, and finds no place for them in his triptych. 
efforts to assimilate and Americanize white Europeans produced it. Bellah's civil religion represents an evolving process initiated by the founders and adjusted in every generation. Likewise, each drew on Durkheim, but in markedly different ways. Herberg rooted his American Way of Life in the unified moral community that represented the end result of Durkheim's definition; Bellah conceived of his civil religion through the component parts that fashioned Durkheim's definition. The American Way of Life frustrated Herberg because he worried about it trivializing Protestant, Catholic, and Jewish claims to identity and values, all of which he preferred to the facile, mundane, and individualistic civic religion. Civil religion invigorated Bellah because he relished the moral imperative embedded in symbols and rituals as well as the opportunity it provided both to critique the nation and to unify a diverse population. ${ }^{21}$ The embrace of civil religion rather than the American Way of Life obscured Herberg's most innovative argument by positioning his view of American Jews as normative Americans as descriptive but not analytic. In turn, Protestant understandings of community and covenant held sway even as "Protestant-Catholic-Jew" came to define mid-twentieth-century American religion.

With "Civil Religion in America", Bellah successfully instigated years of scholarship on civil religion. The foundational status accorded his conception of civil religion, rather than Herberg's American Way of Life, stems in part from Bellah's concrete, process-oriented observations. By highlighting specific rituals, symbols, and language, Bellah created a fertile terrain for debate. Bellah also addressed some of the concerns raises by early reviewers of Protestant-Catholic-Jew: in his hands, civil religion is supple and transcendent rather than censorious and static, and it encouraged conversation rather than limited discussion. The flexibility of Bellah's civil religion, dedicated as it was to reshaping the nation as necessary, underscored his sensitivity to American mores. Toward the end of his essay, he remarked, "If the whole God symbolism requires reformulation, there will be obvious consequences for the civil religion, consequences perhaps of liberal alienation and of fundamentalist ossification that have not so far been prominent in this realm" ([15], p. 15). Amidst the maelstrom of the 1960s, the rumblings of religious division of the public arena remained undetected by many observers. Bellah's instinctive sense that such a divide could occur demanded an implicit recognition of the power of evangelicalism and fundamentalism, religious attitudes Herberg underestimated. This intuition, along with his salient concerns about impending war in Vietnam, contributed to the potency of Bellah's work for it marked the future of American domestic and international politics, which in turn prevented easy discounting of his work.

Finally, Bellah's sweeping assimilation of American historical change through the lens of Protestant culture bolstered the standing of "Civil Religion in America". ${ }^{22}$ Although Herberg used the seemingly objective language of sociology, his analysis depended on his immigrant background and experience within the Jewish community. In Protestant-Catholic-Jew, the American Jewish immigration experience becomes modal and normative. Take, for example, his assessment of Jewish immigrants: "In other words, by being Jewish they were, in a very curious way, becoming more typically American. Basically this was true of most immigrants, but particularly of the Jews, who before long were to

21 In later work, Bellah would demonstrate the force of Herberg's concern with the individual [49].

22 Bellah was raised Presbyterian and became Episcopalian. For more on the religious circles in which he traveled, see ([50], pp. 457-73). 
reveal themselves as, in a certain sense, paradoxically the most 'American' of all the ethnic groups that went into the making of modern America" ([11], p. 10). ${ }^{23}$ Beneath the hedging, Herberg channeled the Jewish experience as the American experience. Although no early reviewers identified this as a feature of the book, it helps explain why the American Way of Life quickly lost cogency and power. His version of civic religion was simultaneously too Jewish and too neo-Orthodox-too tied to particular forms of immigration and too vexed by the future of religion qua religion. Herberg, in other words, was ill-equipped to speak to larger American concerns and worldviews. What accounts for the persistence of "Protestant-Catholic-Jew" as a descriptor of mid-twentieth-century America? Quite simply, regular public stagings of the minister-priest-rabbi trio, exemplified by the National Conference of Christian and Jews "traveling trios" and by the World War II-era military chaplaincy, enacted Protestant-Catholic-Jew as a social reality. ${ }^{24}$ But this symbolic equality, unlike a deep reading the book, did not demand accepting Jews as model or modal Americans.

If Robert Bellah offered a more optimistic civil religion, one that provided the potential for Americans to think hard about nation and society and produced several decades of scholarship, Will Herberg's American Way of Life gestured toward the hard edges of American tolerance and inclusion. ${ }^{25}$ While glib mimicry of Herberg's phrase "Protestant, Catholic, Jew" provides an easy standard against which to measure religious change in America, a deeper and more sophisticated reading of Herberg suggests more stasis than change. Herberg's biggest, and least recognized, intellectual move was moving Judaism from the margin into the mainstream. He took a tiny percentage of the American population and transformed Jews into equals with Protestants and Catholics, while clearly excluding other religious and non-religious Americans. From his perspective, identifying as a Buddhist or a Muslim or "anything but a Protestant, Catholic, or a Jew, even when one's Americanness is otherwise beyond question" was to be "foreign". Similarly, "those who declare themselves atheists, agnostics, or even 'humanists"” was to "imply being obscurely 'un-American"” ([11], pp. 257-58). Thus, the remark from commentator E.J. Dionne that "Protestant-Catholic-Jew-Muslim-Hindu-SikhBuddhist-Jain-Confucian" more aptly depicts twenty-first-century America, is both true and false. While he correctly observes that more religions dot the American religious landscape than ever before, most of them remain on the periphery. In general, Americans tolerate and include Muslims, Hindus, Sikhs, Buddhists, Jains, Confucians, and others. But Americans expect them to make accommodations to the "American Way of Life" or "American Civil Religion". Particularly in a post-September 11th world, Muslims (and often Sikhs, because of their turbans) must show they are dedicated, patriotic Americans without allegiances to terrorists or "Axis-of-Evil" nations. In other words, they must accept a hegemonic conception of civil religion entangled in the mission of white, Protestant nation builders. Instead of developing a more capacious national self-understanding that invites newcomers, the burden rests with non-Protestant, non-Catholic, and non-Jewish Americans to demonstrate their Americanness and practice their religions in ways that do not disturb others. In that regard, in the almost sixty years

23 In a footnote, Herberg makes this claim even more strongly: "Jews, out of their special Jewish background", early fell into the ways that were to become normative for immigrant life in America" ([11], p. 24). Rebecca Gould highlights the ways Protestant-Catholic-Jew is a Jewish text in [51].

24 See ([2], p. 38; [52], pp. 121-23, 258).

25 For recent work on the history of religious toleration in the United States, see [53]. 
since the publication of Protestant-Catholic-Jew, Americans have accepted Will Herberg's construction of American society without attempting to do for post-1968 immigrants what he, despite his indignation toward tepid religiosity, accomplished for pre-1924 immigrants.

\section{Acknowledgments}

Thank you to Darren Dochuk for providing this opportunity; to Deborah Dash Moore who encouraged me to think deeply about the reception and use of Protestant-Catholic-Jew; to Lauren Turek for sharp eyes and constructive critique; and to the two anonymous reviewers for keen insights and helpful feedback.

\section{Conflicts of Interest}

The author declares no conflict of interest.

\section{References and Notes}

1. Reinhold Niebuhr. “America's Three Melting Pots.” The New York Times, 25 September 1955, BR6.

2. Kevin Schultz. Tri-Faith America: How Catholics and Jews Held Postwar America to Its Protestant Promise. New York: Oxford University Press, 2011.

3. Horace Kallen. Cultural Pluralism and the American Idea: An Essay in Social Philosophy. Philadelphia: University of Philadelphia Press, 1956.

4. Milton Gordon. Assimilation in American Life: The Role of Race, Religion, and National Origins. New York: Oxford University Press, 1964.

5. Robert Laurence Moore. Religious Outsiders and the Making of Americans. New York: Oxford University Press, 1986.

6. David Hollinger. Postethnic America: Beyond Multiculturalism. New York: Basic Books, 1996.

7. Martin Marty. The One and the Many: America's Struggle for the Common Good. Cambridge: Harvard University Press, 1997.

8. Diana Eck. A New Religious America: How a "Christian Country" Has Become the World's Most Religiously Diverse Nation. New York: HarperSanFrancisco, 2001.

9. William Hutchison. Religious Pluralism in America. New Haven: Yale University Press, 2003.

10. E.J. Dionne. “A Resilient Christianity.” The Washington Post, 12 April 2009, A17.

11. Will Herberg. Protestant-Catholic-Jew: An Essay in American Religious Sociology. New York: Anchor Books, 1960.

12. Mae Ngai. Impossible Subjects: Illegal Aliens and the Making of Modern America. Princeton: Princeton University Press, 2004.

13. Roger Daniels. Guarding the Golden Door: American Immigration Policy and Immigrants since 1882. New York: Hill and Wang, 2004.

14. Robert Bellah. The Broken Covenant: American Civil Religion in Times of Trial, 2nd ed. Chicago: University of Chicago Press, 1992.

15. Robert Bellah. "Civil Religion in America." Daedalus 96 (1967): 1-21. 
16. James A. Mathisen. "Twenty Years after Bellah: Whatever Happened to American Civil Religion?" Sociological Analysis 50 (1989): 129-46.

17. Philip Gleason. "Looking Back at Protestant-Catholic-Jew." U.S. Catholic Historian 23 (2005): 51-64.

18. Raymond Haberski, Jr. God and War: American Civil Religion since 1945. New Brunswick: Rutgers University Press, 2012. Haberski's book explores the fungible nature of civil religion in postwar America and highlights the political use of the term; although he devotes a couple pages each to both Herberg and Bellah, he does not focus on either their ideas or the intellectual reception of their ideas.

19. Healan Gaston. "The Cold War Romance of Religious Authenticity: Will Herberg, William F. Buckley Jr., and the Rise of the New Right." Journal of American History 99 (2013): 1133-58.

20. Edward Shapiro. "Will Herberg's Protestant-Catholic-Jew: A Critique." In Key Texts in American Jewish Culture. Edited by Jack Kugelmass. New Brunswick: Rutgers University Press, 2003, pp. 258-74.

21. Philip Gleason. Speaking of Diversity: Language and Ethnicity in Twentieth Century America. Baltimore: Johns Hopkins University Press, 1992.

22. Emile Durkheim. The Elementary Forms of Religious Life. Translated by Karen Fields. New York: The Free Press, 1995.

23. D.W. Brogan. "Religion in America." The Manchester Guardian, 1 June 1956, p. 4.

24. John J. Kane. "Review of Protestant-Catholic-Jew." The American Catholic Sociological Review. 17 (1956): 66.

25. S. Joseph Fauman. "Review of Protestant-Catholic-Jew.” Jewish Social Studies 19 (1957): 84.

26. J. Milton Yinger. "Review of Religion in Crisis and Custom and Protestant-Catholic-Jew." American Sociological Review 21 (1956): 237-38.

27. Thomas McAvoy. "Catholic, Protestant, and Jew and Other Problems of Conformity." The Review of Politics 18 (1956): 105.

28. Alban Baer. "Religion in the Melting Pot of America." Commonweal, 13 January 1956, p. 383.

29. H.L. Short. "Boom in Religion." The New Statesman and Nation, 3 March 1956, p. 189.

30. Jack Cohen. "Review of Protestant-Catholic-Jew." The Reconstructionist, 1956, pp. 30-31.

31. John Bennett. "Review of Protestant-Catholic-Jew." Religion in Life: A Christian Quarterly of Opinion and Discussion 25 (1955-1956): 132-33.

32. Gibson Winter. "Review of Protestant-Catholic-Jew." The Journal of Religion 37 (1957): 59-60.

33. Lee Braude. "Review of Protestant-Catholic-Jew." The American Journal of Sociology 61 (1956): 646-47.

34. Samuel Sandmel. "Review of Protestant-Catholic-Jew." American Jewish Archives 9 (1957): 150-51.

35. Harry Ausmus. Will Herberg: From Right to Right. Chapel Hill: University of North Carolina Press, 1987.

36. David S. Fogelsong. The American Mission and the "Evil" Empire. New York: Cambridge University Press, 2007.

37. William Inboden. Religion and American Foreign Policy, 1945-1960: The Soul of Containment. New York: Cambridge University Press, 2008. 
38. Gunn, T. Jeremy. Spiritual Weapons: The Cold War and the Forging of an American National Religion. Westport: Praeger Publishers, 2009.

39. Jonathan Herzog. The Spiritual-Industrial Complex: America's Religious Battle against Communism in the Early Cold War. New York: Oxford University Press, 2011.

40. Andrew Preston. Sword of the Spirit, Shield of Faith: Religion in American War and Diplomacy. New York: Knopf, 2012.

41. Robert Bellah. "A Biography of Robert Bellah.” Available online: http://www.robertbellah.com/ biography.html (accessed on 24 April 2009).

42. Robert Bellah. "Meaning and Modernity: America and the World." In Meaning and Modernity: Religion, Polity, and Self. Edited by Richard Madsen, William Sullivan, Ann Swidler and Steven Tipton. Berkeley: University of California Press, 2002.

43. Robert Bellah. Beyond Belief: Essays on Religion in a Post-Traditional World. Berkeley: University of California Press, 1970.

44. Paul Boyer. By the Bomb's Early Light: American Thought and Culture at the Dawn of the Atomic Age. New York: Pantheon Books, 1985.

45. Stephen J. Whitfield. The Culture of the Cold War. Baltimore: Johns Hopkins University Press, 1991.

46. Christian G. Appy, ed. Cold War Constructions: The Political Culture of United States Imperialism, 1945-1966. Amherst: University of Massachusetts Press, 2000.

47. Wendy Wall. Inventing the "American Way": The Politics of Consensus from the New Deal to the Civil Rights Movement. New York: Oxford University Press, 2008.

48. Matthew Hedstrom. The Rise of Liberal Religion: Book Culture and American Spirituality in the Twentieth Century. New York: Oxford University Press, 2012.

49. Robert Bellah, Richard Madsen, William M. Sullivan, Ann Swidler, and Steven M. Tipton. Habits of the Heart: Individualism and Commitment in American Life. Berkeley: University of California Press, 1985.

50. Robert Bellah. "On Being Catholic and American." In The Robert Bellah Reader. Edited by Robert Bellah and Steven Tipton. Durham: Duke University Press, 2006.

51. Rebecca Gould. "Protestant-Catholic-Jew at Fifty: An Historian's Perspective." U.S. Catholic Historian 23 (2005): 79-86.

52. Deborah Dash Moore. GI Jews: How World War II Changed a Generation. Cambridge: Harvard University Press, 2004.

53. Christopher Beneke, and Christopher Grenda, eds. The Lively Experiment: Religious Toleration in America from Roger Williams to the Present. Lanham: Rowman \& Littlefield, 2015.

(C) 2015 by the authors; licensee MDPI, Basel, Switzerland. This article is an open access article distributed under the terms and conditions of the Creative Commons Attribution license (http://creativecommons.org/licenses/by/4.0/). 